\title{
Physical and Genetic Mapping of the Protein A Gene in the Chromosome of Staphylococcus aureus 8325-4
}

\author{
By ARVIND H. PATEL, ${ }^{2}$ TIMOTHY J. FOSTER ${ }^{2 *}$ AND \\ PETER A. PATTEE ${ }^{1}$ \\ 'Department of Microbiology, Iowa State University, Ames, Iowa 50011, USA \\ ${ }^{2}$ Department of Microbiology, Moyne Institute, Trinity College, Dublin 2, Ireland
}

(Received 10 October 1988; revised 16 February 1989; accepted 4 April 1989)

\begin{abstract}
The gene coding for protein A ( $s p a)$ has been mapped close to nov on the genetic map of the chromosome of Staphylococcus aureus 8325-4. A rapid mapping procedure has been developed which first allowed the region of the chromosome carrying the spa gene to be identified by blot hybridization of large DNA fragments which had been separated by pulsed-field gel electrophoresis. Restriction endonuclease $S m a I$ fragment $G$ was shown to carry the spa gene. An insertion mutation in spa was constructed by in vitro insertion of a fragment of DNA expressing resistance to kanamycin and neomycin. A spa:: $\mathrm{Kan}^{\mathrm{r}} \mathrm{Neo}^{\mathrm{r}}$ mutation was isolated in $S$. aureus $8325-4$ by allele replacement. This provided a selectable marker which allowed the spa gene to be mapped by transformation analysis.
\end{abstract}

\section{INTRODUCTION}

Protein A is a cell-wall-associated protein of the Gram-positive pathogenic bacterium Staphylococcus aureus (for reviews see Langone, 1982; Fosgren et al., 1983). Five repeated domains which bind immunoglobulin molecules at a site on the $\mathrm{Fc}$ region protrude from the cell surface (Löfdahl et al., 1983; Uhlén et al., 1984). The protein is anchored to the cytoplasmic membrane by a hydrophobic C-terminal domain. Region X, part of which comprises tandemly repeated octapeptide units, is responsible for the molecule spanning the peptidoglycan of the cell wall (Guss et al., 1984).

There is evidence that protein $\mathrm{A}$ is a virulence factor of $S$. aureus because it impairs opsonophagocytosis of bacterial cells and because it can induce hypersensitivity, complement activation and histamine release from basophils (Fösgren et al., 1983). There is a correlation between the level of expression of protein $\mathrm{A}$ in natural isolates and their resistance to phagocytosis (Peterson et al., 1977). Also, site-specific protein-A-deficient mutants isolated by gene-replacement are more susceptible to phagocytosis in vitro (C. G. Gemmell, M. R. Tree, A. H. Patel \& T. J. Foster, unpublished).

The genetic map of $S$. aureus strain 8325 has been compiled by recombination analysis using transformation and protoplast fusion (Pattee \& Neveln, 1975; Stahl \& Pattee, 1983a, $b$; Pattee, 1987). Initially, biosynthetic markers and drug resistance determinants were mapped. Transposon mutagenesis extended the range of markers (Pattee, 1981; Schroeder \& Pattee, 1984). However, only one transposon mutation has been reported which affects expression of virulence factors. This strain has a Tn 551 insertion which reduces expression of $\alpha$-toxin (Mallonee et al., 1982) by what is now known to be a mutation in a regulatory locus called agr (Recsei et al., 1986).

\footnotetext{
Abbreviations and genetic symbols: $\mathrm{Amp}^{\mathrm{r}}$, ampicillin resistance; $\mathrm{Cml}^{\mathrm{r}}$, chloramphenicol resistance; Erm ${ }^{\mathrm{r}}$ erythromycin resistance; Etb ${ }^{r}$, ethidium bromide resistance; $\mathrm{Kan}^{r}$, kanamycin resistance; $\mathbf{M e c}^{\mathrm{r}}$, methicillin resistance; $\mathrm{Neo}^{r}$, neomycin resistance; Nov ${ }^{r}$, novobiocin resistance; PGFE, pulsed-field gel electrophoresis.
} 
Three genes encoding virulence factors have so far been mapped on the $S$. aureus chromosome. The enterotoxin A gene which is associated with a converting bacteriophage (Betley \& Mekalanos, 1985) maps in interval 6 (Pattee \& Glatz, 1980) but can occupy other chromosomal sites (Mallonee et al., 1982). The $\alpha$-toxin $(h l y)$ and lipase (geh) genes were inactivated with drug resistance insertion mutations isolated by allele replacement (O'Reilly $e t$ $a l .$, 1986) and plasmid integration (Lee \& Iandolo, 1986), respectively. The integrated drug resistance determinants served as selective markers for the virulence factor loci in mapping experiments (Pattee, 1986, 1987).

In this paper we report that the $S$. aureus 8325 chromosome is cut by the restriction enzyme Smal into 13 fragments ranging from $673 \mathrm{~kb}$ to $36 \mathrm{~kb}$ which have been separated by pulse-field gel electrophoresis. The $S m a I$ fragments have been correlated with the $S$. aureus genetic map) P. A. Pattee, unpublished). The physical and genetic mapping of the protein A gene, spa, in the $S$. aureus chromosome is reported here.

\section{METHODS}

Bacterial strains and plasmids. The $S$. aureus strains are listed in Table 1 and the plasmids in Table 2. Strain 83254 is a derivative of strain 8325 which has been cured of three prophages (Novick, 1963). This accounts for the difference in the SmaI banding pattern of the two strains. Fragment F (208 kb) in the lysogenic strain 8325 is replaced in strain $8325-4$ by a band which comigrates with fragment $\mathrm{H}(135 \mathrm{~kb})$. Fragment $F$ is known to carry att $\phi 11$ and may carry att $\phi 13$. Transduction was performed with phage $\phi 80 \alpha$ as described by Asheshov (1966).

Genetic mapping. DNA used for transformation was prepared as described by Pattee \& Neveln (1975) and transformation was performed as described by Stahl \& Pattee (1983b), except that $1.0 \mathrm{ml}$ of rabbit serum was added to each $100 \mathrm{ml}$ culture of the recipient strain at an $\mathrm{OD}_{540}$ of 0.05 , and the cells were routinely harvested at an $\mathrm{OD}_{540}$ of 0.1. Phage $\phi 55$ was used to promote competence for transformation (Stahl \& Pattee, 1983b) even with strains that were phage $\phi 11$ lysogens. Transformants were selected and scored as described previously (Stahl \& Pattee, 1983b). The kanamycin $\left(\mathrm{Kan}^{r}\right)$ and neomycin $\left(\mathrm{Neo}^{r}\right)$ resistance determinant was selected and scored on $\mathrm{BHI}$ agar containing both drugs at $10 \mu \mathrm{g} \mathrm{ml}^{-1}$. Double selection was necessary to eliminate spontaneous resistant mutants which grew on control plates containing a single aminoglycoside.

Physical mapping. Pulsed-field gel electrophoresis (PFGE) of chromosomal DNA was performed as described by Smith et al. (1986). Low-melting-temperature agarose (FMC) plugs (1\%) containing cells to be analysed were prepared according to Smith et al. (1986). The plugs were incubated at $37^{\circ} \mathrm{C}$ for $18 \mathrm{~h}$ in EC buffer (Smith et al., 1986) containing lysostaphin (Sigma; $0.3 \mathrm{mg} \mathrm{ml}^{-1}$ ) instead of lysozyme to lyse the cells in situ. They were then transferred to ESP buffer (Smith et al., 1986) and incubated at $50^{\circ} \mathrm{C}$ for $48 \mathrm{~h}$. After washing with $10 \mathrm{mM}$-Tris/HCl, $1 \mathrm{mM}$-EDTA pH 7.5 (TE) buffer containing phenylmethylsulphonyl fluoride, and then with TE (Smith et al., 1986), the released DNA was cleaved with SmaI and analysed by PFGE using the vertical apparatus described by Gardiner et al. (1986) at $200 \mathrm{~mA}$ and with a $12 \mathrm{~s}$ pulse time at $17^{\circ} \mathrm{C}$. Details of the physical map of the $S$. aureus 8325 chromosome will be reported elsewhere (P. A. Pattee, unpublished).

DNA hybridization. This was done by the procedure of Southern (1975) as described in Maniatis et al. (1982). Genomic DNA was prepared by the method of O'Reilly et al. (1986). Nitrocellulose membranes were used for DNA transfers, while Hybond-N membranes (Amersham) were used for transfers of DNA separated by PFGE. Probes were labelled either by nick-translation (Rigby et al., 1977) using $\left[\alpha^{-32} \mathrm{P}\right] \mathrm{dATP}$, hybridization being detected by autoradiography, or with photoactivatable biotin ( $N$-[4-azido-2-nitrophenyl]- $N^{\prime}$-[ $N$-d-biotinyl-3aminopropyl]- $N^{\prime}$-methyl-1,3-propanediamine; Clontech Laboratories, Palo Alto, California, USA), hybridization being detected using the Blu-Gene system (Bethesda Research Laboratories).

Recombinant DNA procedures and construction of pEBM155. In vitro manipulation of plasmid DNA was performed by routine procedures (Maniatis et al., 1982). The shuttle plasmid pEBM15, which carries the $\Delta s p a:: E_{t b}^{r}$ mutation linked to pUC18 and pE194, has been described previously (Patel et al., 1987). This plasmid was cleaved partially with HindIII and ligated with the $2.6 \mathrm{~kb}$ HindIII fragment from pBR322-K $\mathrm{an}^{\mathrm{r}} \mathrm{Neor}$. Transformants were selected on agar containing ampicillin $\left(50 \mu \mathrm{g} \mathrm{ml}^{-1}\right)$ and kanamycin $\left(20 \mu \mathrm{g} \mathrm{ml}^{-1}\right)$. Subsequently the presence of the erythromycin resistance $\left(\mathrm{Erm}^{r}\right)$ and ethidium bromide resistance $\left(\mathrm{Etb}^{\mathrm{r}}\right)$ markers was verified. In the recombinant pEBM 155 the $2.6 \mathrm{~kb}$ HindIII $\mathrm{Kan}^{\mathrm{r}} \mathrm{Neo}^{\mathrm{r}}$ fragment was inserted at a HindIII site located within the $2 \mathrm{~kb} \mathrm{Etbr}$ insert used in the original inactivation of spa (Fig. 1).

Isolation of the $S$. aureus $\triangle s p a:: \mathrm{Kan}^{r} \mathrm{NeO}^{r}$ mutation by allele-replacement mutagenesis. The shuttle plasmid carrying the $\Delta s p a:: \mathrm{Etb}^{\mathrm{r}}:: \mathrm{Kan}^{\mathrm{r}} \mathrm{Neo}^{\mathrm{r}}$ mutation was transformed into the Spa ${ }^{-}$strain DU5723 which carries the incompatible plasmid pEC1. Double-plasmid-carrying strains were selected on agar containing kanamycin $(10 \mu \mathrm{g}$ 
Table 1. S. aureas strains

\begin{tabular}{|c|c|c|c|}
\hline $\begin{array}{c}\text { Strain } \\
\text { no. }\end{array}$ & $\begin{array}{l}\text { Parental } \\
\text { strain }\end{array}$ & Genotype & Origin or reference \\
\hline 8325 & & pig-131 & NCTC* \\
\hline $8325-4$ & 8325 & pig-13I & Novick (1963) \\
\hline ISP2 & 8325 & pig-131 nov-142 & Pattee \& Neveln (1975) \\
\hline ISP86 & 8325 & pig-131 uraA141 hisG15 nov-142 purA102 & Pattee (1981) \\
\hline ISP794† & 8325 & pig-131 & Stahl \& Pattee (1983a) \\
\hline ISP1115 & 8325 & $\begin{array}{l}\text { trpE85 uraB232::Tn551 ermB327 Tn4291 nov-142 } \\
\text { tmn-3106 rib-127 } \Omega[\operatorname{Tn} 551] 1051\end{array}$ & Luchansky \& Pattee (1984) \\
\hline DU5819 & $8325-4$ & pig-131 $\Delta$ spa-515::Etbr $:: \mathrm{Kan}^{\mathrm{r}} \mathrm{Neo}^{\mathrm{r}}$ & This study \\
\hline ISP2073 & 8325 & pig-131 $\Delta$ spa-515::Etbr :: $\mathrm{Kan}^{\mathrm{r}} \mathrm{Neo}^{r}$ & $\begin{array}{l}\text { ISP2 } \times \text { DU5819 DNA; } \\
\text { this study }\end{array}$ \\
\hline ISP2162 & 8325 & pig-131 $\Omega[\operatorname{Tn} 551] 1051 \operatorname{Tn} 4291$ & $\begin{array}{l}\text { ISP794 } \times \text { ISP1115 DNA; } \\
\text { this study }\end{array}$ \\
\hline DU5723 & $8325-4$ & pig-131 spa-515::Etb (carries pEC1) & Patel et al. (1987) \\
\hline
\end{tabular}

* NCTC, National Collection of Type Cultures, Colindale, London, UK.

$\dagger$ ISP794 was derived from a transformation cross between two auxotrophic mutants [ISP1 8325 thy-101 pig-131 DNA $\times$ ISP2 8325 nov-142 pig-131] as described by Stahl \& Pattee (1983a). However, genotypically it is identical to NCTC8325 (pig-131).

\section{Table 2. Plasmids}

\begin{tabular}{|c|c|c|c|}
\hline Plasmid & Markers & Properties & Reference \\
\hline pEBM15 & $\mathrm{Amp}^{r} \mathrm{Etb}^{\mathrm{r}} \mathrm{Erm}^{\mathrm{r}}$ & pUC18-pE194 spa::Etb shuttle plasmid & Patel et al. (1987) \\
\hline $\mathrm{pECl}$ & $\mathrm{Cml}^{\mathrm{r}}$ & $\begin{array}{l}\text { pE194 replication origin linked to a } \mathrm{Cml}^{\mathrm{r}} \\
\text { fragment }\end{array}$ & Patel et al. (1987) \\
\hline pEBM155 & $\begin{array}{l}\text { Ampr Etbr Ermr } \\
\text { Kan }^{r} \mathrm{Neo}^{r}\end{array}$ & $\begin{array}{l}\text { pEBM } 15 \text { with a } 2.6 \mathrm{~kb} \text { HindIII fragment } \\
\text { cloned from pBR } 322-\mathrm{Kan}^{r} \mathrm{Neo}^{r} \text {; shuttle } \\
\text { plasmid }\end{array}$ & This study \\
\hline $\begin{array}{l}\text { pBR322- } \\
\text { Kan' Neor }\end{array}$ & $\mathrm{Amp}^{r} \mathrm{Kan}^{r} \mathrm{Neo}^{r}$ & $\begin{array}{l}\text { pBR322 carrying a } 2.6 \mathrm{~kb} \text { HindIII fragment } \\
\text { carrying the Kan } \mathrm{Neo}^{\mathrm{r}} \text { marker derived } \\
\text { from pTC128 }\end{array}$ & $\begin{array}{l}\text { Coleman et al. }(1985) \\
\text { M. Storrs, pers. comm. }\end{array}$ \\
\hline pSPA721 & $\mathrm{Amp}^{r} \mathrm{Erm}^{r} \mathrm{Spa}^{+}$ & $\begin{array}{l}\text { pUC18 with a } 4.35 \mathrm{~kb} \text { fragment carrying spa } \\
\text { from } 8325-4\end{array}$ & Patel et al. (1987) \\
\hline pUC18-EB2 & $A m p^{r} E_{t b}^{r}$ & $\begin{array}{l}2 \mathrm{~kb} \mathrm{BglII} \text { fragment from pJEl cloned at } \\
\text { BamHI site in pUC18 }\end{array}$ & $\begin{array}{l}\text { Evans \& Dyke (1988); } \\
\text { K. Sweeney, pers. comm }\end{array}$ \\
\hline
\end{tabular}

$\left.\mathrm{ml}^{-1}\right)$ and chloramphenicol $\left(\mathrm{Cml}, 10 \mu \mathrm{g} \mathrm{ml}^{-1}\right)$. Cultures were grown to stationary phase in Trypticase Soy Broth containing $\mathrm{Cml}$ to select for $\mathrm{pECl}$, diluted 100 -fold in fresh $\mathrm{Cml}$ broth and grown to stationary phase again. This procedure was repeated until about 100 generations of growth had occurred, and the shuttle plasmid had been eliminated from the population. Double recombinants carrying the $\Delta s p a:: \mathrm{Etb}^{\mathrm{r}}:: \mathrm{Kan}^{r} \mathrm{Neo}^{\mathrm{r}}$ mutation were identified as $\mathrm{Kan}^{r} \mathrm{Neo}^{r} \mathrm{Etb}^{r} \mathrm{Erm}^{\mathrm{s}}$ colonies.

\section{RESULTS}

\section{Isolation and characterization of the $\Delta s p a:: E t b^{r}:: K^{2} n^{r} N e o^{r}$ mutation}

The Etbr marker originally used to inactivate the spa gene is expressed very poorly in the single-copy state and is unsuitable as a selective marker in genetic crosses (Patel et al., 1987). Thus a spa mutation was constructed by the insertion of a DNA fragment containing a $\mathrm{Kan}^{\mathrm{r}} \mathrm{Neo}^{\mathrm{r}}$ marker. A $2.6 \mathrm{~kb}$ HindIII fragment carrying the $\mathrm{Kan}^{\mathrm{r}} \mathrm{Neo}^{\mathrm{r}}$ determinant of pBR322$\mathrm{Kan}^{r} \mathrm{Neo}^{\mathrm{r}}$ was inserted into one of the HindIII sites located within the Etb ${ }^{\mathrm{r}}$ fragment of 

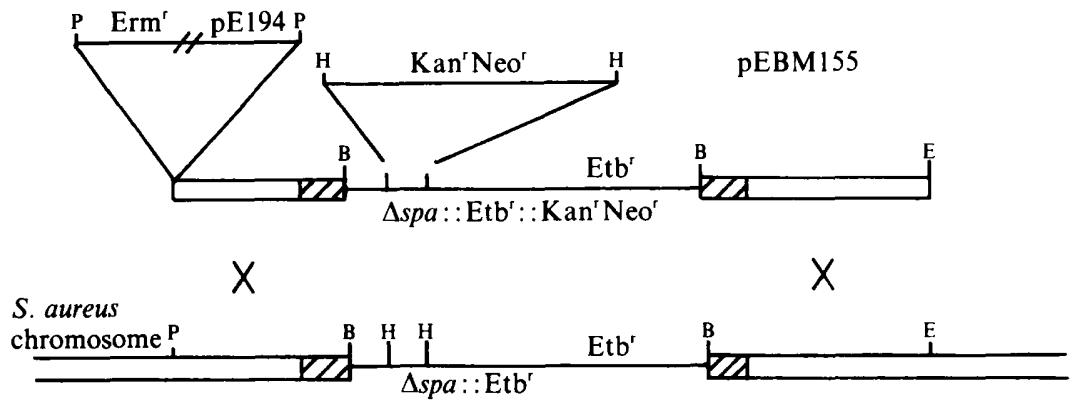

Fig. 1. Structure of pEBM155 and isolation of $S$. aureus spa:: $\mathrm{Kan}^{\mathrm{r}} \mathrm{Neo}^{\mathrm{r}}$ by allele replacement. The parallel lines represent staphylococcal DNA from the spa region in the shuttle plasmid pEBM155 and in the chromosome. The thin line shows the $2 \mathrm{~kb}$ fragment carrying the Etb ${ }^{r}$ marker which substituted for a $1.2 \mathrm{~kb} \mathrm{Bcl}$ I fragment in spa forming $\Delta s p a:: \mathrm{Etb}^{\mathrm{r}}$ (Patel et al., 1987). The cross-hatched areas indicate the parts of the spa gene remaining in the substitution mutation. The crosses indicate the regions in which recombination must have occurred in generating the $\Delta s p a:: \mathrm{Kan}^{\mathrm{r}} \mathrm{Neo}^{\mathrm{r}}$ mutation in the chromosome. The large triangles indicate the positions of the inserted $\mathrm{Kan}^{\mathrm{r}} \mathrm{Neo}^{\mathrm{r}}$ fragment and plasmid pE194. The HindIII site in the $2 \mathrm{~kb} \mathrm{Etb}^{r}$ region which was involved in insertion of the $\mathrm{Kan}^{\mathrm{r}} \mathrm{Neo}^{\mathrm{r}}$ fragment was not determined. Restriction sites are abbreviated as follows: P, Pst I H HindIII ; E, EcoRI; B, hybrid $B c l$ I/BglII site.

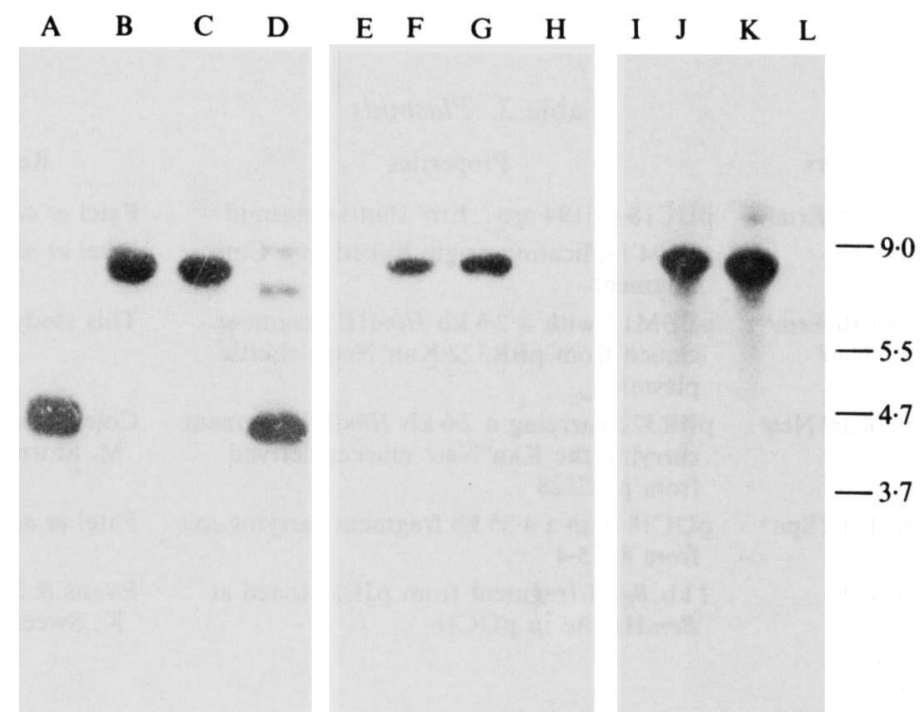

Fig. 2. Southern hybridization. Genomic DNA was cut with EcoRI and probed with ${ }^{32} \mathrm{P}$-labelled plasmid DNA. The spa probe was from pSPA721 (tracks A, B, C and D), the Etb ${ }^{r}$ probe from pUC18EB2 (tracks E, F, G and H) and the $\mathrm{Kan}^{r} \mathrm{Neo}^{\mathrm{r}}$ probe from pBR322-Kan ${ }^{\mathrm{r}} \mathrm{Neo}^{\mathrm{r}}$ (tracks I, J, K and L). Genomic DNA was from strains 8325-4 (tracks A, E and I), DU5819 (tracks B, F and J), ISP2073 (tracks C, G and K) and ISP2 (tracks D, H and L). Standard size markers (kb) are indicated.

pEBM15 to form pEBM155 (Fig. 1). This shuttle plasmid was transferred into $S$. aureus $\Delta s p a:: E^{2} b^{r}$ (DU5723) and a recombinant (DU5819) carrying the $\mathrm{Kan}^{r} \mathrm{Neo}^{r}$ marker at its chromosomal spa locus was isolated. The resulting $\Delta s p a:: E^{t} b^{r}:: K a^{r} N^{2} o^{r}$ mutation was then transformed from the $8325-4$ background into the 8325 derivative ISP2 to form ISP2073. The structure of the altered spa locus in strain DU5819 and ISP2073 was verified by Southern hybridization as indicated below.

Genomic DNA was cleaved with EcoRI, fractionated by agarose gel electrophoresis and hybridized with the following probes : a $4.3 \mathrm{~kb}$ EcoRI fragment (spa probe) carrying the spa gene 


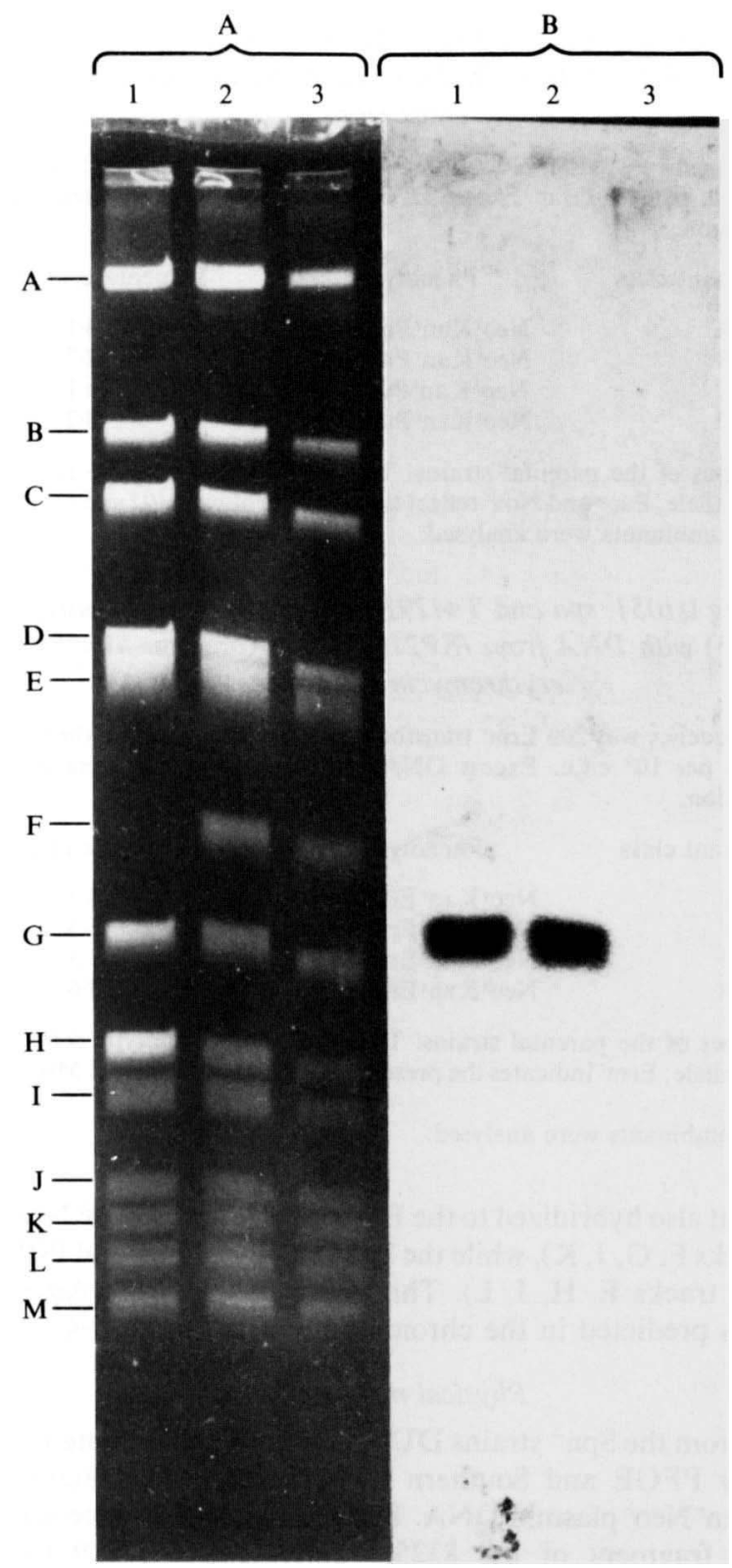

Fig. 3. PFGE in agarose gel and hybridization analysis of spa-515:: $\mathrm{Kan}^{\mathrm{r}} \mathrm{Neo}^{\mathrm{r}}$. A, PFGE gel after staining with ethidium bromide; B, hybridization analysis of the gel in A using biotinylated pBR322$\mathrm{Kan}^{r} \mathrm{NeO}^{\mathrm{r}}$ DNA as a probe. Track 1, DU5819; track 2, ISP2073; track 3, ISP794. The letters at the left identify the SmaI fragment of the $S$. aureus 8325 chromosome: A, $673 \mathrm{~kb} ; \mathrm{B}, 361 \mathrm{~kb} ; \mathrm{C}, 324 \mathrm{~kb} ; \mathrm{D}, 262$ kb; E, 257 kb; F, 208 kb; G, 175 kb; H, 135 kb; I, 117 kb; J, 80 kb; K, 76 kb; L, 44 kb; M, 36 kb.

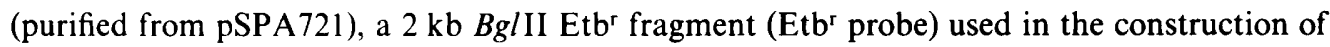
$\Delta s p a:: \mathrm{Etb}^{\mathrm{r}}$ (purified from pUC18-EB2) and a plasmid carrying the $2.6 \mathrm{~kb}$ HindIII $\mathrm{Kan}^{\mathrm{r}} \mathrm{Neo}^{\mathrm{r}}$ fragment $\left(\mathrm{Kan}^{r} \mathrm{Neo}^{r}\right.$ probe) used in constructing $\Delta s p a:: \mathrm{Etb}^{r}:: \mathrm{Kan}^{\mathrm{r}} \mathrm{Neo}^{r}$ (purified from pBR322-Kan $\left.{ }^{r} \mathrm{Neo}^{r}\right)$.

A fragment of $4.3 \mathrm{~kb}$ hybridized with the spa probe in both $8325-4$ and in ISP2 (Fig. 2, tracks A and D) whereas a $7.7 \mathrm{~kb}$ fragment hybridized in strains DU5819 and ISP2073 (Fig. 2, tracks B 
Table 3. Mapping spa, purA102 and nov-142 markers by transformation of DU5819 ( Neor Kant Novs Pur ${ }^{+}$) with DNA from ISP86 (Neos Kan Pur ${ }^{-}$Nov $)$, selecting for novobiocin resistance

The transformation frequency was $280 \mathrm{Nov}^{r}$ transformants per $10^{9} \mathrm{c} . \mathrm{f} . \mathrm{u}$. and the reversion frequency was $<2.9$ Nov $^{\mathrm{r}}$ colonies per $10^{9}$ c.f.u. Excess DNA and $1.7 \times 10^{9}$ c.f.u. were used in $1 \mathrm{ml}$ of the transformation suspension.

Recombinant class

A
B
C
D
Phenotype*

$\mathrm{Neo}^{r} \mathrm{Kan}^{\mathrm{r}} \mathrm{Pur}^{+} \mathrm{Nov}^{\mathrm{r}}$

$\mathrm{Neo}^{r} \mathrm{Kan}^{\mathrm{r}} \mathrm{Pur}^{-} \mathrm{Nov}^{\mathrm{r}}$

$\mathrm{Neo}^{\text {s }} \mathrm{Kan}^{\mathrm{s}} \mathrm{Pur}^{-} \mathrm{Nov}^{\mathrm{r}}$

$\mathrm{Neo}^{\mathrm{s}} \mathrm{Kan}^{\mathrm{s}} \mathrm{Pur}^{+} \mathrm{Nov}^{\mathrm{r}}$
Percentage of total $\uparrow$

$35 \cdot 1$

$38 \cdot 7$

$26 \cdot 1$

$0 \cdot 2$

* See Table 1 for genotypes of the parental strains. The Neor $\mathrm{Kan}^{\mathrm{r}}$ phenotype reflects the presence of the insertionally inactivated spa allele; $\mathrm{Pur}^{-}$and $\mathrm{Nov}^{\top}$ reflect the presence of purA102 and nov-142 alleles, respectively.

$\dagger$ A total of 476 Nov $^{r}$ recombinants were analysed.

Table 4. Mapping $\Omega 1051$, spa and Tn4291 markers by transformation of DU5819 ( $\mathrm{NeO}^{\mathrm{r}} \mathrm{Kan}^{\mathrm{r}} \mathrm{Erm}^{\mathrm{s}} \mathrm{Mec}^{\mathrm{s}}$ ) with DNA from ISP2162 ( Neos $\mathrm{Kan}^{\mathrm{s}} \mathrm{Erm}^{\mathrm{r}} \mathrm{Mec}$ ) with selection for erythromycin resistance

The transformation frequency was $200 \mathrm{Erm}^{\mathrm{r}}$ transformants per $10^{9} \mathrm{c} . \mathrm{f} . \mathrm{u}$. and the reversion frequency was $0.5 \mathrm{Erm}^{\mathrm{r}}$ colonies per $10^{9}$ c.f.u. Excess DNA and $2.0 \times 10^{9}$ c.f.u. were used per ml of the transformation suspension.

Recombinant class

A
B
C
D
Phenotype*

$\mathrm{Neo}^{\mathrm{r}} \mathrm{Kan}^{\mathrm{r}} \mathrm{Erm}^{\mathrm{r}} \mathrm{Mec}^{\mathrm{s}}$

$\mathrm{Neo}^{\mathrm{s}} \mathrm{Kan}^{\mathrm{s}} \mathrm{Erm}^{\mathrm{r}} \mathrm{Mec}^{\mathrm{s}}$

$\mathrm{Neo}^{\mathrm{r}} \mathrm{Kan}^{\mathrm{r}} \mathrm{Erm}^{\mathrm{r}} \mathrm{Mec}^{\mathrm{r}}$

$\mathrm{Neo}^{\mathrm{s}} \mathrm{Kan}^{\mathrm{s}} \mathrm{Erm}^{\mathrm{r}} \mathrm{Mec}^{\mathrm{r}}$
Percentage of total $\dagger$

$24 \cdot 3$

$15 \cdot 3$

$1 \cdot 8$

$58 \cdot 6$

* See Table 1 for genotypes of the parental strains. The Neor $\mathrm{Kan}^{\mathrm{r}}$ phenotype reflects the presence of the insertionally inactivated spa allele; $\mathrm{Erm}^{\mathrm{r}}$ indicates the presence of $\Omega[\mathrm{Tn} 551] 1051$, and $\mathrm{Mec}^{\mathrm{r}}$ reflects the presence of Tn4291.

† A total of $399 \mathrm{Erm}^{\mathrm{r}}$ recombinants were analysed.

and C). A $7.7 \mathrm{~kb}$ fragment also hybridized to the $\mathrm{Etb}^{\mathrm{r}}$ probe and the $\mathrm{Kan}^{\mathrm{r}} \mathrm{Neo}^{\mathrm{r}}$ probe in DU5819 and ISP2073 (Fig. 2, tracks F, G, J, K), while the Spa ${ }^{+}$strains 8325-4 and ISP2 did not hybridize to these probes (Fig. 2, tracks E, H, I, L). This confirmed that the $\Delta s p a::$ Etb $^{r}:: \mathrm{Kan}^{\mathrm{r}} \mathrm{Neo}^{\mathrm{r}}$ mutation was present as predicted in the chromosome of strain 8325-4.

\section{Physical mapping}

Chromosomal DNA from the $\mathrm{Spa}^{-}$strains DU5819 and ISP2073 along with the $\mathrm{Spa}^{+}$control strain were analysed by PFGE and Southern hybridization. The filters were probed with biotinylated pBR322-Kan ${ }^{r} \mathrm{Neo}^{\mathrm{r}}$ plasmid DNA. The $175 \mathrm{~kb}$ SmaI fragment G of strain ISP2073 and the corresponding fragment of the 8325-4 derivative DU5819 hybridized with the $\mathrm{Kan}^{\mathrm{r}} \mathrm{Neo}^{\mathrm{r}}$-specific probe (Fig. 3, tracks A1, B1, A2, B2). In the multiple lysogen 8325, SmaI-G spans the chromosome from $\Omega[\operatorname{Tn} 551] 1023$ to $\Omega[\operatorname{Tn} 551] 1051$ and thus includes $\operatorname{Tn} 4291$ (methicillin resistance [Mecr]; Trees \& Iandolo, 1988), purA102 and nov-142 (Fig. 4; Pattee, 1987; P. A. Pattee, unpublished).

\section{Genetic mapping}

The $\Delta s p a:: \mathrm{Etb}^{\mathrm{r}}:: \mathrm{Kan}^{\mathrm{r}} \mathrm{Neo}^{\mathrm{r}}$ mutation was originally isolated in strain $8325-4$ to form DU5819. The spa mutation was then transformed into the novobiocin-resistant (Novr) strain ISP2. It was observed that selection for the introduction of $s p a:: \mathrm{Kan}^{\mathrm{r}} \mathrm{Neo}^{\mathrm{r}}$ in ISP2 sometimes caused a Nov $v^{s}$ phenotype, suggesting linkage between spa and nov. This finding is consistent with the physical mapping experiment described above.

Linkage between nov and spa was confirmed and quantified by transforming DU5819 (Spa $\left.{ }^{-}\right)$ with DNA isolated from ISP86 (Ura- ${ }^{-} \mathrm{His}^{-} \mathrm{Nov}^{r} \mathrm{Pur}^{-}$) and selecting for $\mathrm{Nov}^{r}$ (Table 3). While 


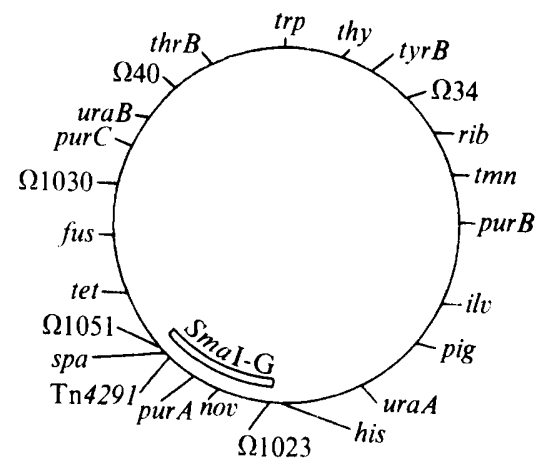

Fig. 4

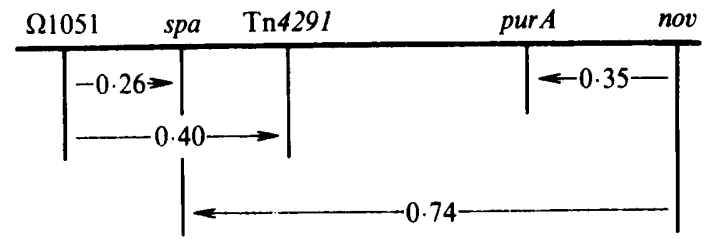

Fig. 5

Fig. 4. Abbreviated chromosome map of $S$. aureus 8325 .

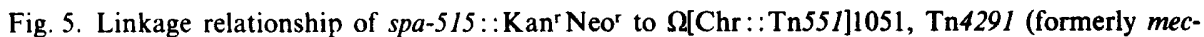
4916), purA102 and nov-142 (Luchansky \& Pattee, 1984; Kuhl et al., 1978; Trees \& Iandolo, 1988). Map distances are calculated from the data in Tables 3 and 4. Map distances between two markers A and B are expressed as 1 minus the estimated co-transformation frequency-(C), where $C=$ frequency of cotransformation of two markers $A$ and $B$ (i.e. $C=A B / A$ or $C=A B / B$ where $A B$ is the recombinant class containing both donor markers $\mathrm{A}$ and $\mathrm{B})$.

uraA141 and hisG 15 segregated independently, the results placed purA102 0.35 map units to the 'left' of nov-142 as previously shown by Stahl \& Pattee (1983a). The results also placed spa (scored as $\mathrm{Kan}^{\mathrm{r}} \mathrm{Neo}^{\mathrm{r}}$ ) 0.74 map units from nov-142 and on the same side as purA102. When DU5819 was transformed with DNA isolated from ISP2162 ( $\left(21051 \mathrm{Erm}^{\mathrm{r}} \mathrm{Mec}^{\mathrm{r}}\right)$, with selection for $\mathrm{Erm}^{\mathrm{r}}$, the results (Tables 3 and 4) placed $\Omega 1051$ and spa to the 'left' of Tn4291 in the order spa- $\Omega 1051-\mathrm{Tn} 4291$. Fig. 5 summarizes the linkage relationships of these markers; Fig. 4 shows the relative location of this region on the chromosome map of $S$. aureus.

\section{DISCUSSION}

This paper describes the application of PFGE to mapping chromosomal genes in $S$. aureus. This technique allows any gene which has been cloned and/or inactivated by insertion mutagenesis to be localized to a segment of the chromosome in a single Southern blot experiment. This information can be used to choose markers for subsequent genetic mapping experiments and may obviate the need to use the laborious procedure of multi-factorial analysis by protoplast fusion (Stahl \& Pattee, 1983a,b) to locate the region of the chromosome involved.

The gene coding for protein $\mathrm{A}$ is only the third exoprotein virulence factor gene of $S$. aureus to be mapped on the chromosome. The availability of an insertion mutation isolated by allele replacement facilitated these mapping experiments. Allele-replacement mutagenesis is a generally applicable technique for isolating insertion mutations in chromosomal genes, but requires the gene in question to be cloned. Despite efforts by several groups, transposongenerated mutations affecting virulence factor or exoprotein genes of $S$. aureus have not been reported, apart from a single Tn551 mutation in agr which causes a pleiotropic regulatory mutation (T. J. Foster \& P. A. Pattee, unpublished). It seems that staphylococcal transposons may show some degree of insertion site specificity.

There is no evidence that virulence factor genes are clustered in any particular region of the chromosome. Here we show that the protein A gene is not linked to genes coding for lipase (Pattee, 1987) or $\alpha$-toxin (Pattee, 1986). Furthermore, sequence analysis of chromosomal genes which code for exoproteins suggests that they are monocistronic (Uhlén et al., 1984; Lee \& Iandolo, 1986; Kaida et al., 1987). In many cases putative transcription termination signals have been identified adjacent to the coding sequences. 
The technical assistance of Robyn Hottman and Teresa Hogan is gratefully acknowledged. This investigation was supported in part by National Science Foundation Grant DMB-8705408 and Biotechnology Action Programme of the Commission of the European Communities contract number BAP-0131-IRL.

\section{REFERENCES}

AsHeSHOV, E. H. (1966). Loss of antibiotic resistance in Staphylococcus aureus resulting from growth at high temperature. Journal of General Microbiology 42, 403-410.

Betley, M. J. \& Mekalanos, J. J. (1985). Staphylococcal enterotoxin A is encoded by a phage. Science 229, 185-187.

Coleman, D. C., Pomeroy, H., Estridge, J. K., Keane, C. T., Cafferkey, M. T., Hone, R. \& FosTER, T. J. (1985). Susceptibility to antimicrobial agents and analysis of plasmids in gentamicin- and methicillin-resistant Staphylococcus aureus from Dublin hospitals. Journal of Medical Microbiology 20, 157-167.

Evans, J. \& Dyke, K. G. H. (1988). Characterization of the conjugation system associated with the Staphylococcus aureus plasmid pJE1. Journal of General Microbiology 134, 1-8.

Fosgren, A., Ghetite, V., Lindmark, R. \& SJÖQUIST, J. (1983). Protein A and its exploitation. In Staphylococci and Staphylococcal Infections, vol 2, pp. 429-478. Edited by C. S. F. Easmon \& C. Adlam. London: Academic Press.

Gardiner, K., LaAs, W. \& Patterson, D. (1986). Fractionation of large mammalian DNA restriction fragments using vertical pulsed-field gradient gel electrophoresis. Somatic Cell and Molecular Genetics 12, 185-195.

Guss, B., Uhlén, M., Nilsson, B., LindberG, M., SuöQUiST, J. \& SJÖDAHL, J. (1984). Region X, the cellwall-attachment part of staphylococcal protein A. European Journal of Biochemistry 138, 413-420.

Kaida, S., MiYata, T., Yoshizawa, Y., Kawabata, S., Morita, T., Igarashi, H. \& Iwanaga, S. (1987). Nucleotide sequence of the staphylocoagulase gene: its unique $\mathrm{COOH}$-terminal 8 tandem repeats. Journal of Biochemistry 102, 1177-1186.

Kuhl, S. A., Pattee, P. A. \& Baldwin, J. N. (1978). Chromosomal map location of the methicillin resistance determinant in Staphylococcus aureus. Journal of Bacteriology 135, 460-465.

Langone, J. J. (1982). Protein A of Staphylococcus aureus and related immunoglobulin receptors produced by streptococci and pneumococci. Advances in Immunology 32, 157-252.

LEE, C. Y. \& IANDOLo, J. J. (1986). Lysogenic conversion of staphylococcal lipase is caused by insertion of the bacteriophage L54a genome into the lipase structural gene. Journal of Bacteriology 166, 385-391.

Löfdahl, S., Guss, B., Uhlén, M., Philipson, L. \& LINDBERG, M. (1983). Gene for staphylococcal protein A. Proceedings of the National Academy of Sciences of the United States of America 80, 697-701.

LUChansky, J. B. \& PATTEE, P. A. (1984). Isolation of transposon Tn551 insertions near chromosomal markers of interest in Staphylococcus aureus. Journal of Bacteriology 159, 894-899.
Mallonee, D. H., Glatz, B. A. \& Pattee, P. A. (1982). Chromosomal mapping of a gene affecting enterotoxin A production in Staphylococcus aureus. Applied and Environmental Microbiology 43, 397--402.

Maniatis, T., Fritsch, E. F. \& SambrooK, J. (1982). Molecular Cloning: a Laboratory Manual. Cold Spring Harbor, NY: Cold Spring Harbor Laboratory.

Novick, R. P. (1963). Properties of a cryptic highfrequency transducing phage in Staphylococcus aureus. Virology 33, 155-166.

O'Reilly, M., DE AZavedo, J. C. S., Kennedy, S. \& FosTER, T. J. (1986). Inactivation of the alphahaemolysin of Staphylococcus aureus $8325-4$ by sitedirected mutagenesis and studies on expression of its haemolysins. Microbial Pathogenesis 1, 125-138.

Patel, A. H., Nowlan, P., Weavers, E. D. \& Foster, T. J. (1987). Virulence of protein A-deficient and alpha-toxin-deficient mutants of Staphylococcus aureus isolated by allele-replacement. Infection and Immunity 55, 3103-3110.

Pattee, P. A. (1981). Distribution of Tn551 insertion sites responsible for auxotrophy on the Staphylococcus aureus chromosome. Journal of Bacteriology 145, 479-488.

Pattee, P. A. (1986). Chromosome map location of the alpha-hemolysin structural gene in Staphylococcus aureus NCTC 8325. Infection and Immunity 54, 593596.

Pattee, P. A. (1987). Staphylococcus aureus. Genetic Maps 4, 148-154.

Pattee, P. A. \& Glatz, B. A. (1980). Identification of a chromosomal determinant of enterotoxin A production in Staphylococcus aureus. Applied and Environmental Microbiology 39, 186-193.

Pattee, P. A. \& Neveln, D. S. (1975). Transformation analysis of three linkage groups in Staphylococcus aureus. Journal of Bacteriology 124, 201-211.

Peterson, P. K., Verhoef, J., Sabath, L. D. \& Quite, P. G. (1977). Effect of protein A on staphylococcal opsonization. Infection and Immunity 15, 760-764.

RecSei, P., Kreiswirth, B., O'Reilly, M., SchlieVert, P., Gruss, A. \& Novick, R. P. (1986). Regulation of exoprotein gene expression in Staphylococcus aureus by agr. Molecular and General Genetics 202, 58-61.

Rigby, P. W. J., Diekman, M., Rhodes, C. \& Berg, P. (1977). Labelling deoxyribonucleic acid to high specific activity in vitro by nick translation with DNA polymerase. Journal of Molecular Biology 113, 237-251.

Schroeder, C. J. \& Pattee, P. A. (1984). Transduction analysis of transposon $\operatorname{Tn} 551$ insertions in the trp-thy region of the Staphylococcus aureus chromosome. Journal of Bacteriology 157, 533-537.

Smith, C. L., Warburton, P. E., GaAl, A. \& Cantor, C. R. (1986). Analysis of genome organization and rearrangement by pulsed-field gradient gel electro- 
phoresis. In Genetic Engineering, Principles and Methods, pp. 45-70. Edited by J. K. Setlow \& A. Hollaender. New York: Plenum Press.

SOUTHERN, E. M. (1975). Detection of specific sequences among DNA fragments separated by gel electrophoresis. Journal of Molecular Biology 98, 503-517.

Stahl, M. L. \& Pattee, P. A. (1983a). Computerassisted chromosome mapping by protoplast fusion in Staphylococcus aureus. Journal of Bacteriology 154, 395-405.

Stahl, M. L. \& Pattee, P. A. (1983b). Confirmation of protoplast fusion-derived linkages in Staphylococcus aureus by transformation with protoplast DNA. Journal of Bacteriology 154, 406-412.

TreEs, D. L. \& IANDoLo, J. J. (1988). Identification of a Staphylococcus aureus transposon $(\operatorname{Tn} 4291)$ that carries the methicillin resistance gene(s). Journal of Bacteriology 170, 149-154.

Uhlén, M., Guss, B., Nilsson, B., Gatenbeck, S., Philipson, L. \& LindberG, M. (1984). Complete sequence of the staphylococcal gene encoding protein A. A gene evolved through multiple duplications. Journal of Biological Chemistry 259, 1695-1702. 